\title{
小判断裁包装の自動化
}

山陽国策パルプ粉小松島工場 吉 永 兼 吉

\section{The Automatical Lines of Cut-size Sheet}

\author{
Kenkichi Yoshinaga \\ Sanyo-Kokusaku Pulp Co., Ltd. Komatsushima Mill
}

Out line of our cut-sized sheet lines is introduced and operational experience and quality assuarance of our cut-sized sheets are explained.

Keywords: Cut-size installation, Packaging, Cartoning, Palletizing, Quality assuarance.

\section{1. はじめに}

$\mathrm{OA}$ 機器の急速な普及とともに，ここ数年来 PPC 用紙をはじめカット紙の需要が伸びて来ているが，当 工場ではカット紙の生産体制として昭和 56 年より小 判断裁包装の自動化ラインを 3 系列稼働させており, さらに現在， 1 系列の増設工事を実施中である。

自動化ラインは抄紙工程からの原反受け入れに始ま り断裁, 包装, 箱詰, 荷造までの工程を連続化したも のでそのために, 中間自動會庫を設けカッタースタン ト, 小判カッター, 小判包装機, 自動ケーサー, パレ タイザー, 自動相包機の各機器をコンベアーで接続し ている。ここでは連続化設䚚の概要と安定操業達成ま での経過について述べる。

\section{2. 設 備 概要}

\section{1）中間自動倉庫}

全体レイアウトを図1に示す。
ストッパー付傾斜床式のラインを 20 列配置し, 抄紙 工程から送られて来た原反を順番に自動的に格納する。 自社開発の方式によるもので約 $500 t$ の容量があり, カッタースタンドへの引き込みも自動的に行われる。

2) カッタースタンド

シャフトレス式 5 本掛け固定スタンドで, 原反はチ エーンコンペアーでスタンド内に搬入し，リフターで 自動セットする。

シートランは上引とし, ペーパーロールおよびその フレームを略して紙継作業性を良くした。枓替時間は 約 10 分である。（図 2）

3) 小判カッター

小判カッター 3 台の内 2 台は西独 Will 社のッイン ローターシンクロフライ型, 他の 1 台は米国 Lenox 社のコンベンショナル型である。ここでは Will カッ ターについて概要を述べる。

(1) 概 要

型式 SLK 170 型

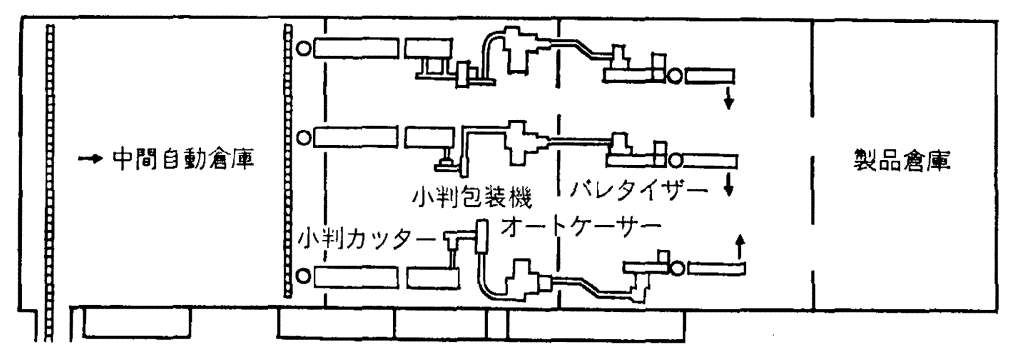

图 1 小判設備レイアウト 


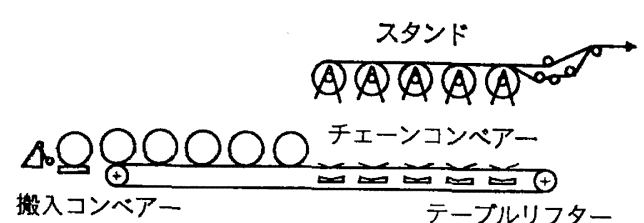

図 2 カッタースタンド

取幅最大 $1700 \mathrm{~mm}$

断裁寸法 B 4 タテ及びA 4 タテ

常用速度 $\quad 180 \sim 230 \mathrm{~m} / \mathrm{min}$

（2）クロスカット部；精密ギャーで上下ナイフドラ ムを連結したサイズ別専用ユニットであり，断裁 精度が高い。ナイフドラムには大径のものが使用 され高速断载適性がねらわれている。ナイフはス パイラル状に 2 又は 3 枚が取付けられ，長時間に わたり切口品質が持続される。ナイフ寿命はコン ベンショナルの 10 倍以上である。

(3) オーバーラップ部；カットされたシートの走行 安定性をよりょくするため，大きなオーバーラッ プ量 $(70 \%)$ て運転するが，安定した高速断载が 行えるかどらかは，オーバーラップ部の機模が重 要である。Will カッターではオーバーラップフ インガー方式では满足な運転が行われている。

(4) コレクティング部；コレクティング部はシート を高速で所定枚数集積し奇麗に揃兄排出して行く。 言わば小判カッターの特改的部分で，カッターの 安定運転並びに, 品質面に影遙することが多く, 多少オーパーな表現をすれば，コレクティング部 を制すれば小判カッターを制すると言ってもよい。 Will カッターでは 1-トレイ方式で, 图4 の如
くフィンガーが下降して一時的に後続シートを保 持し，その間に集積シート（リーム）をグリッパ 一で取り出す。このサイクルはカッタースタンド 5 本掛，断裁速度 $220 \mathrm{~m} / \mathrm{min}, 500$ 枚/りームの 場合，A 4 判で 9.0 秒サイクルといらように，高 速で繰り返されるため，コレクティング部で正常 な運転が行われることが自動化の最大のポイント となる。

4）小判包装機

包装形式は図 5 の様にアンダーホールド式である。 包装の主要部は全てカム機構で確実にタイミングをと って包装されていく。特にェレベーターとホルタ゚ーと の作動タイミングびレベル関俰が重要である。

5) 自動ヶーサー

リーム集積部, 充埧部, ケース成型, 糊付部, 段ボー ルシート供給部よりなっている。自動安定運転には段 ボールシートの品質(カール等)管理がポイントとなる。

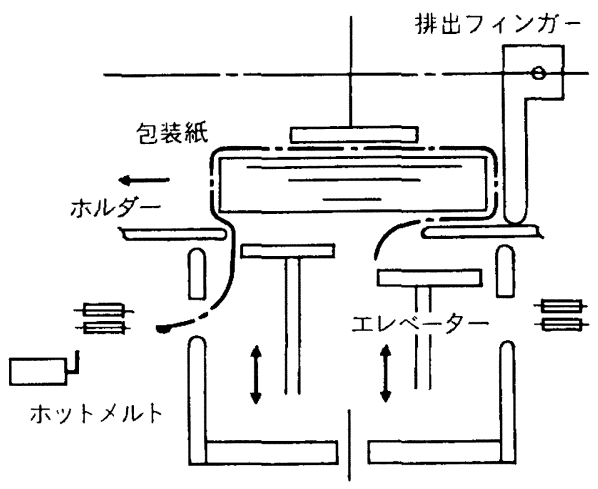

図 5 小判包装機

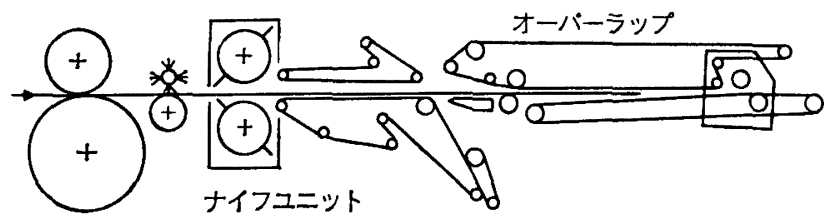

图3クロスカッター
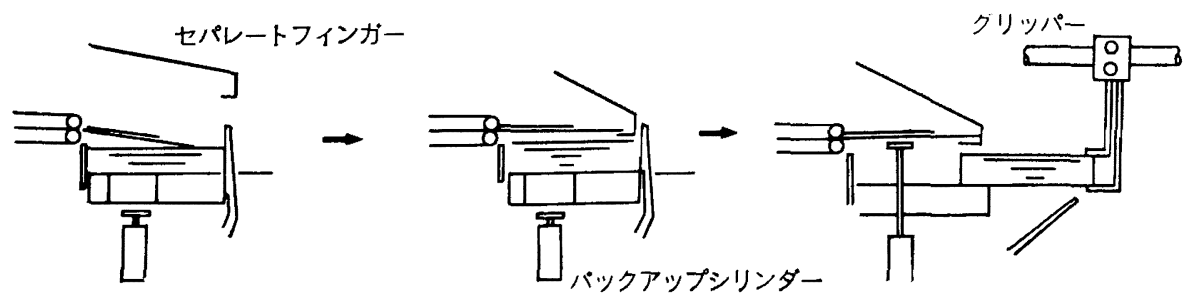

图 4 コレクティング部 
6) パレタイザー

パレット並びにトップ段ボールシートの自動供給装 置を備え自動積み付けされる。

7）自動梱包機

ストレッチフイルム式で全自動運転をしている。 PPC 用紙のパレット棝包住内では, 初めてストレッ チフイルムを採用した。製品内容が外観から見える， 物流トラブルが少ない，包材の処理が楽であること等 により最近ではストレッチフイルム方式が一般化して いる。

8）各パート間の接続コンペアー

小判カッター, 小判包装機, 自動ケーサー, パレタ イザー，自動相包機の各工程間を接続するために，そ れぞれに適応する接続コンベアーを開発した。接続部 ではタイミングの調整および欠陥品の検出を目的とし たシステムが組み込まれている。

特に重要なのは包装機へ接続するコンベアーでカッ ターコレクティング部からリームを受けてシートズレ， 折れ，污れ等を発生させることなく且つ，包装機のイ ンフィードコンベアーと完全なタイミングをとって, 包装機内ヘリームを送り込む必要があり, 連続化の決 め手ともいえる。

\section{3. 安定運転と品質保証}

自動化ライン 3 系列のねらいは処理能力增強と共に, 寸法別に専用ライン化することによって, 生産効亱の 向上と操業及び品質の安定を目指したことにあるが, 現在この目的は達成されたと考えている。

\section{1）自動化ラインの安定運転}

ライン化実施直後は各工程間にクッションが取れな い為に，どこかの工程でトラブルが発生すると全ライ ンが停止し，生産性が思らようにあがらなかった。そ こで問題解決のため, 工務部門と生産現場が一体とな って技術開発を進め, 工程の改良に努めるとともに, TPM 及び小集団活動を軸としてオペレーター全員で 対応に取り組んだ。

（1）きめ細かい設供改善の実施；全ラインにわたっ て一つ一つトラブルの発生源をつぶしていく設借 改善運動を展開した。

（2）設備管理の徽底; 始業点検, 定期点検項目を整 理し, 給油管理も含めて工務部門と現場の責任分 担を明確化し設備管理を徽底した。

(3) オペレーターの技術レベルの向上; 自動化ライ ンの運転には機械と䉓気両方の知識を必要とする。 そのため工務部門て順次教育を行 鉸に务め，特に制御シーケンスは全員が語めるこ
とを目標としたっ、現在, 簡単な制御関係の調整,

修理はオペレーターが実施している。

以上に述べた技術開発及び TPM 活動之小集団活動 による対応が自動化ラインの安定運転に大きく寄与し ていると考えている。

2）品質保証

当工場の品質保証体系にもとづき, 後工程には不良 品を送らない事を基本に設備面とオペレーターの意識 面から, 不良発生要因の楱隇と品質チェック体制の充 実を図って来た。品質チェツク項目としては

(1) カッター；寸法, 菱, 切りロ, ブロッキンック, 污れ, 侮付, 折れ, シワ, シートズレ, カール, 枚数

（2）包装機；污れ，折れ，伤付，タイト性，糊付， 糊転移, 破れ

（3）ケーサー；ケース成形，糊付，污れ，リーム侮， リーム数

等であり，外観的品質項目が大きなウェートを占めて いる。これらの欠陌は工程変動時（例えば急停止，寸 法替, ロット替, 用具部品替等）に発生しやすく, 非 連続の場合が多い。このようなことを念頭において， 品質保証作業規準を制定しているが，この規準は随時 改訂を行いさらに, 完全品質保証を行らためオペレー ター全員の品質意識の高揚活動に力を入れている。

\section{4. 今後の課題}

小判製品は PPC 用紙を中心に伸びて来たが，今後 $\mathrm{OA}$ 機器の進展に伴い市場ニーズはますます多様化, 小ロット化へ進むと考えられる。今後, 小ロット生産 への対応と, 生産性の一㬝の向上のために技術開発が 必要である。また, 完全連続断裁のためカッタースタ ンドの自動紙継システムの開発も重要課題であるが, いずれも設備費を安価にすることが必須条件である。

\section{5. おわりに}

小判製品はそのままの荷姿で最終消費者に渡るもの であり，いわゆる商品として完全品質保証が望まれる。 これを達成するためには抄紙工程から始まり断裁, 包 装, 栶包, 出荷まで一連の工程で品筫保証のための技 術開発の推進とTPM, 小集団活動などによる従業員 の意識と技術レベルの一層の向上が大切であろうと考 えている。

\footnotetext{
一尚，本稿をまとめるにあたり一部資料の引用に ついて機械メーカーのご了解を頂きましたこと に括礼を申しあげます。一
} 